\title{
The Essential Oil Composition of Trachymene incisa Rudge subsp. incisa Rudge from Australia ${ }^{\dagger}$
}

\author{
Jesús Palá-Paúl ${ }^{1, *}$, Lachlan M. Copeland ${ }^{2}$ and Joseph J. Brophy ${ }^{3}$ \\ 1 Departamento Biodiversidad Ecología y Evolución, Facultad de Biología, Universidad Complutense de \\ Madrid, 28040 Madrid, Spain \\ 2 Eco Logical Australia, 24 Gordon St, Coffs Harbour, NSW 2450, Australia; Lachlanc@ecoaus.com.au \\ 3 School of Chemistry, The University of New South Wales, Sydney, NSW 2052, Australia; \\ J.Brophy@unsw.edu.au \\ * Correspondence: Quibey@bio.ucm.es \\ + Part of this paper has been presented as a poster at the 38th International Symposium on Essential Oils, Graz, \\ Austria, 9-12 September 2007.
}

Citation: Palá-Paúl, J.; Copeland, L.M.; Brophy, J.J. The Essential Oil Composition of Trachymene incisa Rudge subsp. incisa Rudge from Australia. Plants 2021, 10, 601. https://doi.org/10.3390/ plants10030601

Academic Editor: Filippo Maggi

Received: 23 February 2021

Accepted: 18 March 2021

Published: 23 March 2021

Publisher's Note: MDPI stays neutral with regard to jurisdictional claims in published maps and institutional affiliations.

Copyright: () 2021 by the authors. Licensee MDPI, Basel, Switzerland. This article is an open access article distributed under the terms and conditions of the Creative Commons Attribution (CC BY) license (https:// creativecommons.org/licenses/by/ $4.0 /)$.

\begin{abstract}
Trachymene incisa subsp. incisa is an Australian endemic taxon that varies greatly in the abundance and length of the leaf trichomes. The essential oil composition of five populations of this subspecies, three corresponding to the typical glabrous form and two of the particularly hairy variant, has been analyzed in an attempt to determinate if that variability is also reflected in their composition. The oils have been extracted by hydrodistillation and analyzed by Gas Chromatography (GC) and Gas Chromatography coupled to Mass Spectrometry (GC-MS). The essential oils of T. incisa subsp. incisa were characterized by the high amount of sesquiterpenes that were the major fraction. The sesquiterepene hydrocarbons were significantly higher in the hairy variant in comparison to the glabrous one. According to the main compound, three different chemotypes were found: I.- $\beta$ selinene + bicyclogermacrene and II. $-\gamma$-bisabolene $+\alpha$-pinene for the typical glabrous variant and III.-bicyclogermacrene $+\beta$-caryophyllene for the hairy variant.
\end{abstract}

Keywords: Trachymene incisa; Apiaceae; chemotype; $\beta$-selinene; bicyclogermacrene; $\gamma$-bisabolene; $\alpha$-pinene; $\beta$-caryophyllene; essential oil; chemical composition

\section{Introduction}

The genus Trachymene Rudge belongs to the Apiaceae family and comprises at least 56 species of herbs, distributed in Australia, New Guinea, the Philippine Islands, Borneo, New Caledonia, Vanuatu and Fiji. Of those, 38 species are native to Australia with a wide diversity of habitats ranging from deserts to alpine areas. The taxonomy of this genus has been controversial throughout history because of the numerous synonyms and the plasticity of some of the species [1]. The type section, Trachymene sect. Trachymene, includes perennial species with functionally bicarpellate fruits [2].

Trachymene incisa Rudge subsp. incisa (Figure 1) is an erect or ascending perennial herb up to $80 \mathrm{~cm}$ high with a thick rootstock. The plants have highly variable dissected basal leaves and one or more rosettes attached to the rootstock. The leaves are sparsely hairy to almost glabrous, the lamina broad ovate, $14-65 \mathrm{~mm}$ long, 15-76 mm wide; segments elliptic or linear, $0.5-6 \mathrm{~mm}$ wide. Plants have bisexual white flowers, clustered into simple umbels with a mean of 72 flowers per umbel. The fruits are broad ovate and are $2-4 \mathrm{~mm}$ long, 2.5-4.0(-7.5) mm wide, brown; occasionally developing only one mericarp. Mericarps are 1.8-2.0(-3.8) mm wide; smooth orbiberculate to papillate schizocarps. It flowers most of the year, peaking between September and April. The dispersal takes place from March to October with no obvious peak. It grows commonly in dry eucalypt woodland or scrub, sclerophyll forest and cleared areas on sandy soils and on rocky granite outcrops and 
resprouts from the tuberous taproot after fire. It is distributed widely throughout eastern NSW north from Ulladulla and into Queensland [1,3-9].

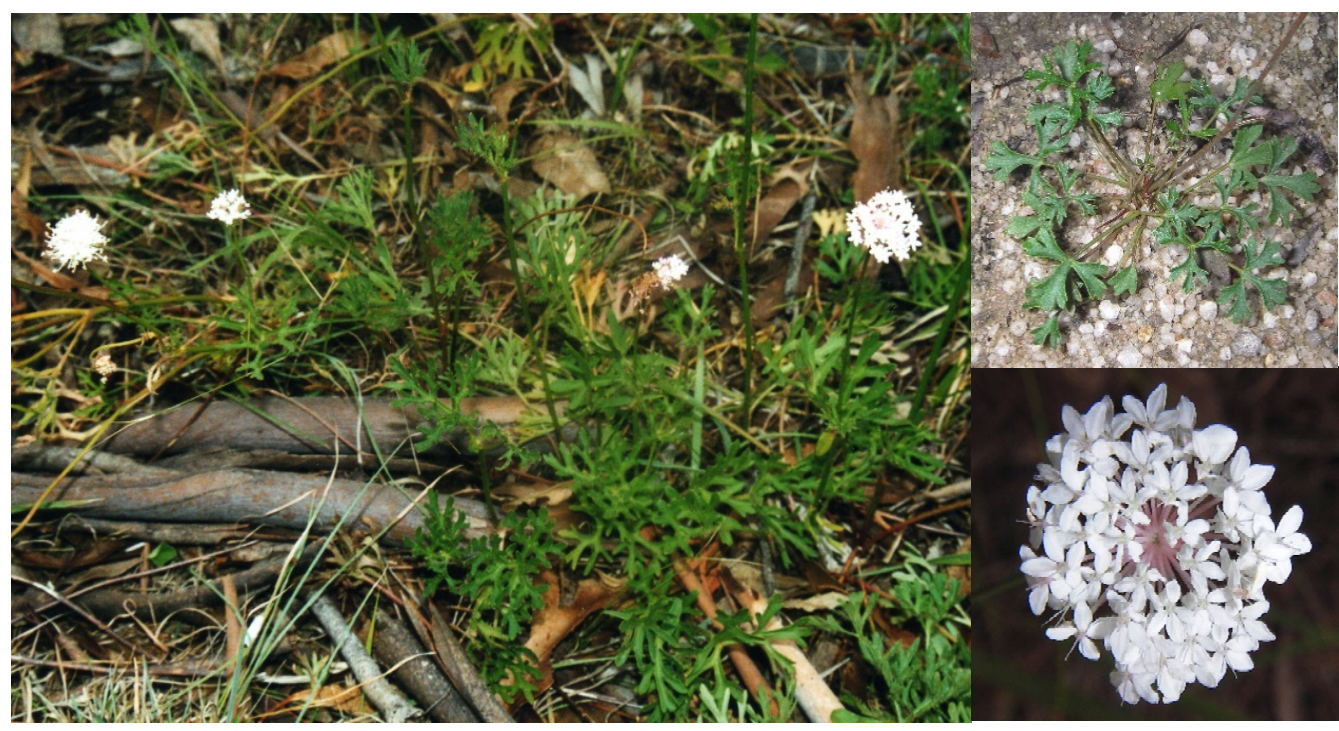

Figure 1. Trachymene incisa Rudge subsp. incisa. Details of the basal leaves and umbel.

Research on this genus has focused on medicinal or ecological aspects. In southwest Queensland and northwest New South Wales, different species of Trachymene (T. glaucifolia (F. Muell.) Benth., T. cyanantha Boyland and T. ochracea L.A.S. Johnson) seem to be toxic to cattle [10-14]. The only herbarium voucher of them corresponded to T. glaucifolia that seems to be directly correlated to a form of "staggers" in sheep and the deformity "bent leg" in lambs [13]. Further research has correlated the intake of T. ochracea with the limb paresis syndrome, included in the first level of the five progressive clinical groups described of the nervous and muscular locomotor disorders that affect sheep throughout Australia [14]. The genus Trachymene has been also reported to show teratogenic compounds that affect the development of an embryo in pregnancy or may cause a birth defect in the child [15]. On the other hand, the niche and competitive ability between T. cyanopetala (F. Muell.) Benth. and T. ornata (Endl.) Druce was evaluated, although little evidence was found under well-watered and water-stressed conditions [16]. Phytophthora caetorum (Lebert and Cohn) Schroeter is a pathogen fungus that attacks T. caerulea R. Grah., the blue lace flower that is field-grown for the cut-flower industry, although the use of hymexazol $(35 \mathrm{mg} / \mathrm{L})$ reduced significantly the symptoms [17]. Another species, T. pilosa Sm., has been described as a resistant and key symptomless host of a relative pathogen P. cinnamomi Rands. However, under laboratory conditions, this species died [18-20]. The resistance of the exine from the mature pollen grains of this species has been estimated [21]. The regeneration ability of T. coerulea Graham under experimental conditions showed that the center of the shoot apex produced fewer mature leaves and fewer embryos from the basal tissues than did the flanks [22]. Finally, the importance of this genus is clear when species such as T. cussonii (Montrouz.) B.L. Burtt have been described as a coral cay endemic plant representative to the conservation of this type of habitat $[23,24]$.

This species has been previously reported as being a member of the Woodland endangered ecological community [25]. However, most of the papers focus on its reproductive ecology, pollination and germination $[4,7,26,27]$.

The aim of this research was to contribute to the knowledge of the essential oil composition of Trachymene incisa subsp. incisa and evaluate if the abundance of trichomes can affect the composition. Apart from our preliminary conference report, as far as we know this is the first report about the chemical composition of the essential oil of this species, or the genus. 


\section{Results and Discussion}

The distillation of the aerial parts of five different populations of T. incisa subsp. incisa yielded small amounts of a pale yellow oil $(0.05-0.17 \%)$. The amount of oil obtained was reduced in comparison with other members of the Apiaceae that are well known and used as condiment or spices $[28,29]$. However, it would be of interest to check other species of this genus to contrast this.

The identified constituents from the aerial parts of T. incisa subsp. incisa, their retention indices and their percentage composition are summarized in Table 1, where all the compounds are arranged in order of their elution from the DB-Wax column. The chromatograms of each analyzed sample and their peak identification and included in the Supplementary Material (Figure S1 and Table S1). From all the samples analyzed, 47 compounds have been identified, representing from $88.4 \%$ to $93.5 \%$ of the total oil. The sesquiterpene fraction predominates, both quantitatively and qualitatively, in all the samples examined, with a total of 33 constituents. Sesquiterpene hydrocarbons (48.3-74.8\%) were more abundant than oxygenated sesquiterpene (6.59-36.2\%). It is worth nothing the low amount of monoterpene fraction and practically the absence of the oxygenated ones, that only appear in T.in. $\mathrm{I}_{3}(9.0 \%)$. The synthesis of terpenoids is correlated from the lower molecular weight to the higher $[30,31]$, so this species has increased the metabolism that produces sesquiterpenes using monoterpenes as precursors. That could explain the low amount of monoterpenes detected. However, it should be interesting to make a seasonal study of the population 3 (T.in. $\mathrm{I}_{3}$ ) to know if the amount of $\alpha$-pinene is constant throughout the cycle of the plant or if it could be conditioned by other factors.

Table 1. Essential oil composition (\%) of Trachymene incisa subsp. incisa variants.

\begin{tabular}{|c|c|c|c|c|c|c|c|c|c|c|c|}
\hline KIa. & $\mathrm{KI}^{1}$ & $\mathrm{KIb}$ & $\mathrm{KI}^{2}$ & Compound & C. Type & T.in. $I_{1}$ & T.in. $\mathbf{I}_{2}$ & T.in. $\mathbf{I}_{3}$ & T.in.II 4 & T.in.II 5 & I.M. \\
\hline 1007 & 1025 & 932 & 936 & $\alpha$-pinene & $\mathrm{MH}$ & 7.2 & & 19.2 & $t$ & 0.1 & KI, MS \\
\hline 1034 & 1061 & 945 & 949 & $\alpha$-fenchene & $\mathrm{MH}$ & & & 0.8 & & & KI, MS \\
\hline 1041 & 1068 & 946 & 950 & camphene & MH & & & $\mathrm{t}$ & & & KI, MS \\
\hline 1084 & 1110 & 974 & 978 & $\beta$-pinene & $\mathrm{MH}$ & 0.4 & & 2.2 & $\mathrm{t}$ & 0.1 & KI, MS \\
\hline 1105 & 1122 & 969 & 973 & sabinene & $\mathrm{MH}$ & & & & & & KI, MS \\
\hline 1127 & 1146 & 1008 & 1011 & $\delta$-3-carene & $\mathrm{MH}$ & & & 1.8 & & & KI, MS \\
\hline 1139 & 1167 & 1002 & 1004 & $\alpha$-phellandrene & $\mathrm{MH}$ & & & 1.2 & & & KI, MS \\
\hline 1141 & 1160 & 988 & 989 & myrcene & MH & $\mathrm{t}$ & & & & & KI, MS \\
\hline 1157 & 1177 & 1014 & 1017 & $\alpha$-terpinene & $\mathrm{MH}$ & & & & & & KI, MS \\
\hline 1176 & 1198 & 1024 & 1029 & limonene & $\mathrm{MH}$ & $\mathrm{t}$ & & 0.8 & & & KI, MS \\
\hline 1178 & 1209 & 1025 & 1030 & $\beta$-phellandrene & $\mathrm{MH}$ & & & $\mathrm{t}$ & & & $\mathrm{KI}, \mathrm{MS}$ \\
\hline 1181 & 1211 & 1026 & 1031 & 1,8-cineole & $\mathrm{OM}$ & $\mathrm{t}$ & & 9.0 & & & KI, MS \\
\hline 1218 & 1234 & 1032 & 1038 & $Z$ - $\beta$-ocimene & $\mathrm{MH}$ & & & $\mathrm{t}$ & & & $\mathrm{KI}, \mathrm{MS}$ \\
\hline 1224 & 1245 & 1054 & 1059 & $\gamma$-terpinene & $\mathrm{MH}$ & & & $\mathrm{t}$ & & & $\mathrm{KI}, \mathrm{MS}$ \\
\hline 1226 & 1250 & 1044 & 1048 & $E$ - $\beta$-ocimene & $\mathrm{MH}$ & & & $\mathrm{t}$ & & & KI, MS \\
\hline 1249 & 1270 & 1020 & 1024 & $p$-cymene & $\mathrm{MH}$ & $\mathrm{t}$ & $\mathrm{t}$ & 0.6 & $\mathrm{t}$ & $\mathrm{t}$ & KI, MS \\
\hline 1260 & 1282 & 1086 & 1086 & terpinolene & $\mathrm{MH}$ & & $t$ & 0.4 & 0.9 & & KI, MS \\
\hline 1320 & 1237 & 989 & 986 & 6-methylhept-5-en-2-one & $\mathrm{O}$ & & $t$ & 0.2 & $\mathrm{t}$ & $\mathrm{t}$ & KI, MS \\
\hline 1459 & 1469 & 1335 & 1337 & $\delta$-elemene & $\mathrm{SH}$ & 0.3 & 0.3 & & $\mathrm{t}$ & & $\mathrm{KI}, \mathrm{MS}$ \\
\hline 1462 & 1491 & 1374 & 1376 & $\alpha$-copaene & $\mathrm{SH}$ & $\mathrm{t}$ & 3.4 & & $\mathrm{t}$ & & KI, MS \\
\hline 1510 & 1541 & 1387 & 1387 & $\beta$-cubebene & $\mathrm{SH}$ & & 0.6 & & $\mathrm{t}$ & & KI, MS \\
\hline 1523 & 1559 & 1411 & 1414 & $\alpha$-cis-bergamotene & $\mathrm{SH}$ & & & 0.6 & 0.4 & & KI, MS \\
\hline 1543 & 1575 & 1432 & 1435 & $\alpha$-trans-bergamotene & $\mathrm{SH}$ & & 0.2 & 2.1 & $\mathrm{t}$ & & $\mathrm{KI}, \mathrm{MS}$ \\
\hline 1560 & 1590 & 1389 & 1390 & $\beta$-elemene & $\mathrm{SH}$ & 0.8 & 2.9 & 0.4 & $\mathrm{t}$ & & KI, MS \\
\hline 1563 & 1598 & 1417 & 1420 & $\beta$-caryophyllene & $\mathrm{SH}$ & 2.5 & 5.4 & 1.2 & 10.8 & 10.4 & KI, MS \\
\hline
\end{tabular}


Table 1. Cont.

\begin{tabular}{|c|c|c|c|c|c|c|c|c|c|c|c|}
\hline KIa. & $\mathrm{KI}^{1}$ & $\mathrm{KIb}$ & $\mathrm{KI}^{2}$ & Compound & C. Type & T.in. $I_{1}$ & T.in. $\mathrm{I}_{2}$ & T.in. $\mathrm{I}_{3}$ & T.in.II 4 & T.in.II ${ }_{5}$ & I.M. \\
\hline 1570 & 1620 & 1439 & 1441 & aromadendrene & $\mathrm{SH}$ & 1.5 & 0.6 & 0.5 & 5.6 & 5.0 & KI, MS \\
\hline 1572 & 1629 & 1509 & 1504 & $\alpha$-bulnesene & $\mathrm{SH}$ & 0.5 & & $\mathrm{t}$ & 1.2 & 0.9 & KI, MS \\
\hline 1632 & 1649 & 1458 & 1460 & allo-aromadendrene & $\mathrm{SH}$ & 0.2 & 0.4 & 0.4 & 0.4 & 0.4 & KI, MS \\
\hline 1644 & 1664 & 1454 & 1456 & (E)- $\beta$-farnesene & $\mathrm{SH}$ & & 0.3 & 1.4 & 0.6 & & $\mathrm{KI}, \mathrm{MS}$ \\
\hline 1653 & 1666 & 1452 & 1453 & $\alpha$-humulene & $\mathrm{SH}$ & 0.5 & 1.5 & 0.3 & 1.8 & 1.8 & KI, MS \\
\hline 1658 & & & & $\mathrm{C}_{15} \mathrm{H}_{24}$ & $\mathrm{SH}$ & 0.4 & 0.3 & 0.7 & & & KI, MS \\
\hline 1661 & 1696 & 1496 & 1492 & viridiflorene & $\mathrm{SH}$ & 1.9 & 0.8 & 0.6 & 5.4 & 4.7 & KI, MS \\
\hline 1670 & 1708 & 1484 & 1480 & germacrene-D & $\mathrm{SH}$ & 1.4 & 2.4 & 1.5 & 0.5 & & $\mathrm{KI}, \mathrm{MS}$ \\
\hline 1680 & 1705 & 1505 & 1512 & $\gamma$-bisabolene & $\mathrm{SH}$ & & & 27.4 & & & KI, MS \\
\hline 1697 & 1717 & 1489 & 1486 & $\beta$-selinene & $\mathrm{SH}$ & 36.7 & 11.9 & 0.5 & 1.8 & & KI, MS \\
\hline 1706 & 1734 & 1500 & 1494 & bicyclogermacrene & $\mathrm{SH}$ & 28.0 & 21.5 & 7.5 & 34.7 & 24.4 & KI, MS \\
\hline 1722 & 1763 & 1513 & 1513 & $\gamma$-cadinene & $\mathrm{SH}$ & $\mathrm{t}$ & & & & & $\mathrm{KI}, \mathrm{MS}$ \\
\hline 1724 & 1755 & 1522 & 1521 & $\delta$-cadinene & $\mathrm{SH}$ & $\mathrm{t}$ & 9.0 & 0.5 & 1.5 & 1.7 & KI, MS \\
\hline 1727 & 1788 & 1495 & 1531 & cis-cadina-1,4-diene & $\mathrm{SH}$ & & 0.3 & & $\mathrm{t}$ & & KI, MS \\
\hline 1734 & 1744 & 1505 & 1504 & $(\mathrm{E}, \mathrm{E})-\alpha$-farnesene & $\mathrm{SH}$ & $\mathrm{t}$ & 1.4 & 2.6 & & 1.6 & $\mathrm{KI}, \mathrm{MS}$ \\
\hline 1749 & 1773 & 1479 & 1482 & ar-curcumene & $\mathrm{SH}$ & & $\mathrm{t}$ & $\mathrm{t}$ & 0.7 & 1.1 & KI, MS \\
\hline 1886 & 1986 & 1582 & 1580 & caryophyllene oxide & OS & 1.6 & 2.3 & 0.2 & 1.0 & 12.8 & KI, MS \\
\hline 1958 & 2039 & 1602 & 1582 & ledol & OS & 0.2 & 0.2 & 0.1 & 0.5 & $\mathrm{t}$ & KI, MS \\
\hline 2016 & 2067 & 1645 & 1636 & cubenol & OS & $\mathrm{t}$ & 0.9 & 0.2 & 0.8 & 1.5 & $\mathrm{KI}, \mathrm{MS}$ \\
\hline 2018 & 2074 & 1595 & 1588 & cubeban-11-ol & OS & 0.7 & 0.4 & 0.4 & 1.6 & 1.1 & $\mathrm{KI}, \mathrm{MS}$ \\
\hline 2034 & 2082 & 1590 & 1582 & globulol & OS & 2.0 & 1.5 & 1.3 & 7.0 & 6.9 & KI, MS \\
\hline 2044 & 2090 & 1592 & 1591 & viridiflorol & OS & 1.5 & 1.1 & 0.8 & 3.9 & 3.5 & KI, MS \\
\hline 2066 & & & & $\mathrm{C}_{15} \mathrm{H}_{26} \mathrm{O}$ & OS & 0.5 & 0.3 & 0.3 & 2.2 & 2.0 & $\mathrm{KI}, \mathrm{MS}$ \\
\hline 2074 & & & & $\mathrm{C}_{15} \mathrm{H}_{26} \mathrm{O}$ & OS & 0.4 & 0.6 & 0.3 & 1.3 & 1.0 & $\mathrm{KI}, \mathrm{MS}$ \\
\hline 2078 & & & & $\mathrm{C}_{15} \mathrm{H}_{26} \mathrm{O}$ & OS & 0.2 & 0.3 & & & & KI, MS \\
\hline 2086 & 2127 & 1577 & 1576 & spathulenol & OS & 4.2 & 11.2 & 2.9 & 6.7 & 7.5 & KI, MS \\
\hline & & & & & Total & 93.5 & 81.7 & 91.0 & 91.1 & 88.4 & \\
\hline \multicolumn{5}{|c|}{ Monoterpene Hydrocarbon (MH) } & 16 & 7.6 & 0 & 27.0 & 0.9 & 0 & \\
\hline \multicolumn{5}{|c|}{ Oxygenated Monoterpene (OM) } & 1 & 0 & 0 & 9.0 & 0 & 0 & \\
\hline \multicolumn{5}{|c|}{ Sesquiterpene Hydrocarbon (SH) } & 23 & 74.8 & 63.0 & 48.3 & 65.4 & 52.0 & \\
\hline \multicolumn{5}{|c|}{ Oxygenated Sesquiterpene (OS) } & 10 & 11.1 & 18.7 & 6.5 & 24.8 & 36.3 & \\
\hline \multicolumn{5}{|c|}{ Other $(\mathrm{O})$} & 1 & 0 & 0 & 0.2 & 0 & 0 & \\
\hline \multicolumn{5}{|c|}{ Total } & 51.0 & 93.5 & 81.7 & 91.0 & 91.1 & 88.2 & \\
\hline
\end{tabular}

C. type = Compound type $\mathrm{MH}=$ monoterpene hydrocarbon, $\mathrm{OM}=$ oxygenated monoterpene, $\mathrm{SH}=$ sesquiterpene hydrocarbon, $\mathrm{SO}=$ oxygenated sesquiterpene, $\mathrm{O}=$ Other; $\mathrm{t}=$ traces $(<0.1 \%)$; KIa and $\mathrm{KIb}=$ linear retention index relative to $\mathrm{n}$-alkanes on DB-Wax column or DB-5 column respectively; $\mathrm{KI}^{1}$ and $\mathrm{KI}^{2}=$ literature linear retention index on DB-Wax column and DB-5 column respectively [48]; T.In. = Trachymene incisa subsp. incisa; I and II = typical glabrous and hairy variant respectively; I.M. = Identification method.

According to our results, the abundance of trichomes seems to affect the composition of the essential oils of Trachymene incisa subsp. incisa (Table 1). Although the terpenoid distribution seems similar between both glabrous and hairy variants, the amount of sesquiterpene hydrocarbons is significantly higher in the hairy one (Figure 2). Only five populations were analyzed and no climatic or biological conditions were registered. Thus, further study should be done to confirm this or to check if the age of the plant, the presence of pathogen or the climatic condition could affect the chemical composition. Previous reports have confirmed that the phenology of the plant and the growing conditions can affect the essential oils of other species of the same family [32-34]. It has been noted that the density of seeds affects the germination of this species [7], so the competition between growth in the plants could also alter its chemistry as allelopathic compounds do [35-37]. In fact, the 
competition has been reported to have an effect on the phylogenetic signal and phenotypic plasticity in plant functional traits and to the root biomass [38,39]. More work is required to check under laboratory conditions if any of these aspects are involved in the abundance and length of the leaf trichomes of this subspecies.

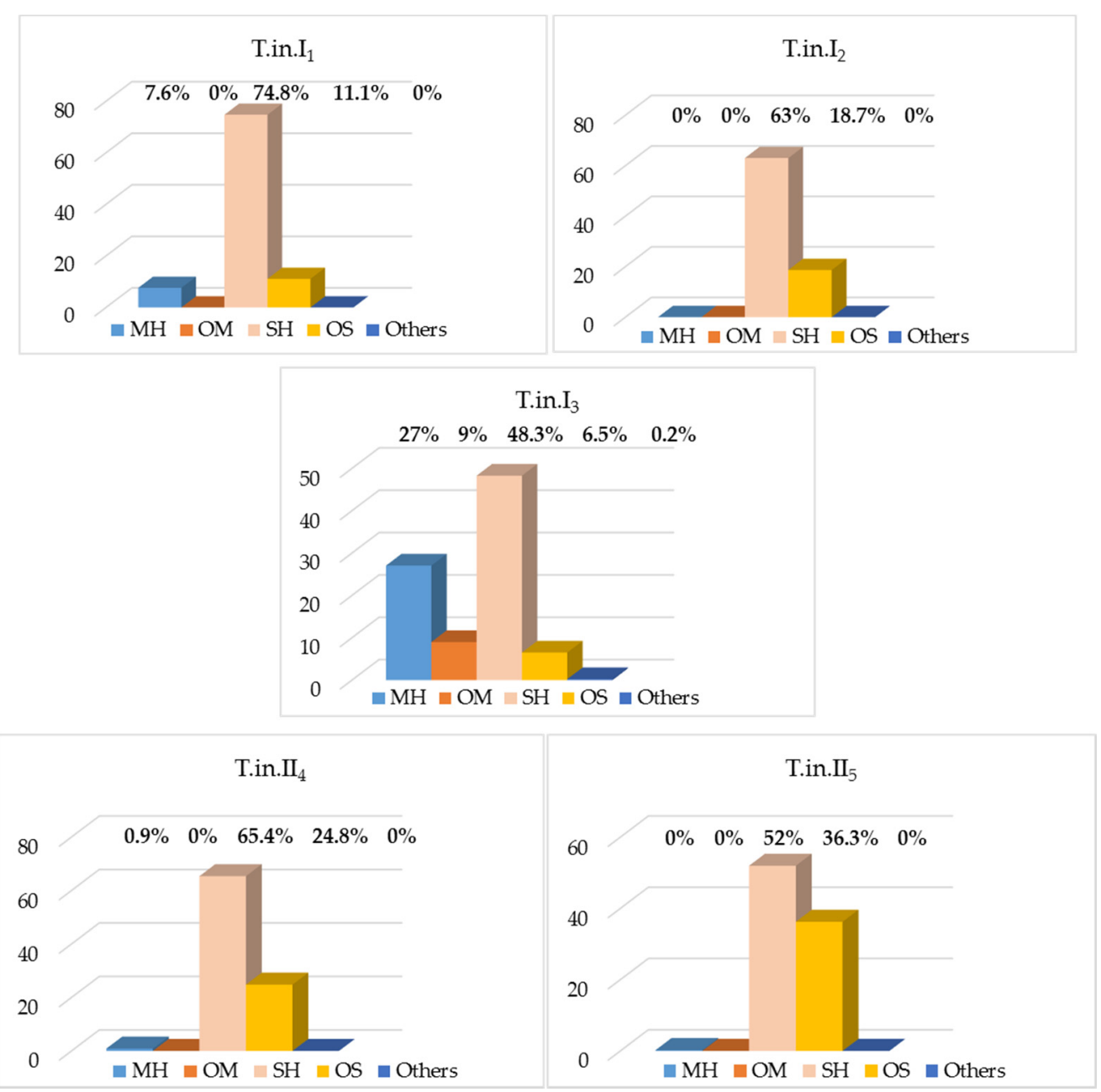

Figure 2. Distribution of the compound type of the essential oils of T. incisa subsp. incisa (T.In. = Trachymene incisa subsp. Incisa; I and II = typical glabrous and hairy variant, respectively).

With respect to the chemical composition of the volatile oils, T. incisa subsp. incisa exhibits the same plasticity in its vegetative and reproductive forms. The typical glabrous variant (T.in.I), showed $\beta$-selinene (11.9-36.7\%) and bicyclogermacrene (21.5-28.0\%) as main compounds in populations 1 and 2 . However, the principal components of the hairy variant (T.in.II) were identified as bicyclogermacrene (24.4-34.7\%) and $\beta$-caryophyllene $(10.4-10.8 \%)$ in populations 4 and 5 , although population 5 also contained a high amount of caryophyllene oxide (12.8\%). According to these results, it seems that each variant has a characteristic composition, but population 3 belonging to the typical glabrous variant (T.in.I) showed other chemotype, with $\gamma$-bisabolene (27.4\%) and $\alpha$-pinene (19.2\%) being the major compounds. According to the main compound, three different chemotypes could be defined: I. $-\beta$-selinene + bicyclogermacrene and II. $-\gamma$-bisabolene $+\alpha$-pinene for the typical glabrous variant and III.- bicyclogermacrene $+\beta$-caryophyllene for the hairy variant, though more sampling of the species would be needed to confirm this.

With this paper, we contribute for the first time to the knowledge of the chemistry of the genus Trachymene. It would be interesting to study the effects of climate, light or soil conditions on the chemical composition of this species to confirm the chemotypes 
described. The diversity of this genus could also be the source of further investigations to characterize their essential oils.

\section{Materials and Methods}

\subsection{Plant Material}

Five different populations of Trachymene incisa subsp. incisa were gathered at flowering from the Northern Tablelands of New South Wales in 2007 (Table 2). Voucher specimens were lodged at the N.C.W. Beadle Herbarium of the University of New England, Australia (NE).

Table 2. Location of the populations of Trachymene incisa subsp. incisa studied.

\begin{tabular}{|c|c|c|c|}
\hline Sample & Voucher $\mathbf{n}^{\circ}$ & Location & Yield \\
\hline T.in. $I_{1}$ & LMC4175 & \multirow{4}{*}{ Single National Park: (NSW, Australia) 20 km NW of Guyra (24 March 2007) } & $0.05 \%$ \\
\hline T.in. $I_{2}$ & LMC4176 & & $0.17 \%$ \\
\hline T.in. $I_{3}$ & LMC4211 & & $0.05 \%$ \\
\hline T.in.II 4 & LMC4210 & & $0.05 \%$ \\
\hline T.in.II ${ }_{5}$ & LMC4234 & $\begin{array}{c}\text { Dumaresq Dam: (NSW, Australia) Along southwestern side of Dumaresq Dam, c. } 10 \mathrm{~km} \\
\text { NW of Armidale (14 April 2007) }\end{array}$ & $0.1 \%$ \\
\hline
\end{tabular}

T.In = Trachymene incisa subsp. incisa; I and II = typical glabrous and hairy variant respectively.

\subsection{Isolation of Volatile Oils}

The oils were isolated by steam distillation with cohobation for $8 \mathrm{~h}$ as previously described by Brophy et al. [40]. The oils were colorless to pale yellow, with a yield from $0.05 \%$ to $0.17 \%$ based in dry weight (Table 2 ).

\subsection{Identification of Components}

Analytical gas chromatography (GC) was carried out on a Shimadzu GC17A gas chromatograph with a Megabore column of DB-Wax $(60 \mathrm{~m} \times 0.5 \mathrm{~mm} \times 1 \mu \mathrm{m})$ which was programmed from 50 to $220^{\circ} \mathrm{C}$ at $3{ }^{\circ} \mathrm{C} \mathrm{min}{ }^{-1}$ with helium as the carrier gas. Injection temperature and detector temperature were both $220^{\circ} \mathrm{C}$. GC integrations were performed on a SMAD electronic integrator. GC-MS was carried out on a Shimadzu GCMS-QP5000 mass spectrometer operating at $70 \mathrm{eV}$ ionization energy. The $\mathrm{GC}$ column used was a DB-wax $(30 \mathrm{~m} \times 0.25 \mathrm{~mm} \times 0.25 \mu \mathrm{m})$ programmed from 35 to $220^{\circ} \mathrm{C}$ at $3{ }^{\circ} \mathrm{C} \mathrm{min}{ }^{-1}$ with helium as the carrier gas, injection temperature and ion source temperature were both $250{ }^{\circ} \mathrm{C}$. Compounds were identified by their GC retention indices relative to n-alkanes and known compounds and by comparison of their full-scan mass spectra with either known compounds or published spectra [41-48]. The oil sample was also analyzed on the same GC-MS system and under the same conditions as above except that a DB-5 $(30 \mathrm{~m} \times 0.25 \mathrm{~mm} \times 0.25 \mu \mathrm{m})$ column was used, programmed from 35 to $250{ }^{\circ} \mathrm{C}$ at $5{ }^{\circ} \mathrm{C}$ $\mathrm{min}^{-1}$ with helium as the carrier gas. In all cases, the mass spectrometer was scanned from $m / z 41$ to $m / z 450$ amu in $1 \mathrm{~s}$.

\section{Conclusions}

According to our results detailed above, the essential oils of Trachymene incisa subsp. incisa are characterized by a high amount of sesquiterpenes that were the major compounds. The sesquiterepene hydrocarbons were significantly more abundant in the hairy variant in comparison to glabrous form. It may be that three different chemotypes occur, with the typical glabrous variant showing two different chemotypes, characterized by: $\beta$-selinene + bicyclogermacrene and $\gamma$-bisabolene $+\alpha$-pinene, while the hairy variant was characterized by bicyclogermacrene $+\beta$-caryophyllene. 
Supplementary Materials: The following are available online at https://www.mdpi.com/2223 -7747/10/3/601/s1, Figure S1: Chromatograms of each sample analized, Table S1: Essential oil composition (\%) of Trachymene incisa subsp. incisa variants with peak mumbers.

Author Contributions: L.M.C. was responsible for gathering and identifying the species. All the authors have contributed equally to the rest of the paper. All authors have read and agreed to the published version of the manuscript.

Funding: This research received no external funding.

Acknowledgments: We would like to express our deepest gratitude to the late Robert J. Goldsack for his friendship and collaboration throughout the years. Rest in peace.

Conflicts of Interest: The authors declare no conflict of interest.

\section{References}

1. Hart, J.M.; Henwood, M.J. A revision of Australian Trachymene (Apiaceae: Hydrocotyloideae). Aust. Syst. Bot. 2006, 19, 11-57. [CrossRef]

2. Keighery, G.J.; Rye, B.L. A taxonomic revision of Trachymene sect. Dimetopia (Apiaceae). Nuytsia 1999, 13, 33-59.

3. Powell, J.M. Apiaceae. In Flora of New South Wales; Harden, G.J., Ed.; New South Wales University Press: Sydney, Australia, 1992; Volume 3, pp. 87-116.

4. Benson, D.; McDougall, L. Ecology of Sydney plant species: Part 1: Ferns, fern-allies. cycads, conifers and dicotyledon families Acanthaceae to Asclepiadaceae. Cunninghamia 1993, 3, 257-422.

5. Davila, Y.C. Reproductive Ecology of Trachymene incisa (Apiaceae). Bachelor's Thesis, The University of Sydney, Sydney, Australia, 1999.

6. Watson, C. Root Demography of an Australian herb: Trachymene incisa. Bachelor's Thesis, University of Sydney, Sydney, Australia, 2000.

7. Gill, K. Seed Dispersal in Trachymene incisa (Apiaceae): The Process and Consequences for the Population. Bachelor's Thesis, University of Sydney, Sydney, Australia, 2000.

8. Davila, Y.C.; Wardle, G.M. Reproductive ecology of the Australian herb Trachymene incisa subsp. incisa (Apiaceae). Aust. J. Bot. 2002, 50, 619-626. [CrossRef]

9. Wardle, G.M. Experimental determination of seed emergence and carry-over in the soil seed bank of the herbaceous perennial, Trachymene incisa (Apiaceae). Austral Ecol. 2003, 28, 161-172. [CrossRef]

10. Edgar, G.; Ropert, J. The toxicity of Didiscus glaucifolius, 'wild parsnip', for sheep. Aust. Vet. J. 1942, 18, 125-126. [CrossRef]

11. Clark, L.; Carlisle, C.H.; Beasley, P.S. Observations on the pathology of bent leg of lambs in south-western Queensland. Aust. Vet. J. 1975, 51, 4-10. [CrossRef]

12. Clark, L. Trachymene spp and inferitility in sheep. Aust. Vet. J. 1977, 53, 249-250. [CrossRef] [PubMed]

13. Philbey, A.W. Trachymene glaucifolia associated with bentleg in lambs. Aust. Vet. J. 1990, 67, 468. [CrossRef] [PubMed]

14. Bourke, C.A. The clinical-differentiation of nervous and muscular locomotor disorders of sheep in Australia. Aust. Vet. J. 1995, 72, 228-234. [CrossRef]

15. Alamgir, A.N.M. Medicinal, Non-medicinal, Biopesticides, Color- and Dye-Yielding Plants; Secondary Metabolites and Drug Principles; Significance of Medicinal Plants; Use of Medicinal Plants in the Systems of Traditional and Complementary and Alternative Medicines (CAMs). In Therapeutic Use of Medicinal Plants and Their Extracts; Progress in Drug Research; Springer: Cham, Switzerland, 2017; Volume 73, pp. 61-104. [CrossRef]

16. Staples, T.L.; Dwyer, J.M.; Loy, X.; Mayfield, M.M. Potential mechanisms of coexistence in closely related forbs. Oikos 2016, 125, 1812-1823. [CrossRef]

17. Wick, R.L.; Rane, K.K.; Sutton, D.P. 2 New ornamental hosts for Phytophthora cactorum-Trachymene caerulea and Gypsophila paniculata. Plant Dis. 1987, 71, 281. [CrossRef]

18. Crone, M.; McComb, J.A.; O’Brien, P.A.; Hardy, G.E.S.J. Annual and herbaceous perennial native Australian plant species are symptomless hosts of Phytophthora cinnamomi in the Eucalyptus marginata (jarrah) forest of Western Australia. Plant Pathol. 2013, 62, 1057-1062. [CrossRef]

19. Crone, M.; McComb, J.A.; O’Brien, P.A.; Hardy, G.E.S.J. Assessment of Australian native annual/herbaceous perennial plant species as asymptomatic or symptomatic hosts of Phytophthora cinnamomi under controlled conditions. For. Pathol. 2013, 43, 245-251. [CrossRef]

20. Crone, M.; McComb, J.A.; O'Brien, P.A.; Hardy, G.E.S.J. Survival of Phytophthora cinnamomi as oospores, stromata, and thick-walled chlamydospores in roots of symptomatic and asymptomatic annual and herbaceous perennial plant species. Fungal Biol. 2013, 117, 112-123. [CrossRef] [PubMed]

21. Audran, J.C. Degeneration of Trachymene-pilosa exine by osmium-tetroxide used in impregnation technique. Planta 1981, 152, 282-284. [CrossRef] [PubMed]

22. Ball, E.A. Regeneration from isolated portions of the shoot apex of Trachymene coerulea RC Grah. Ann. Bot. 1980, 45, 103-112. [CrossRef] 
23. Batianoff, G.N. Coral cay terrestrial flora changes at Lady Elliot Island, Great Barrier Reef, Australia. Proc. R. Soc. Qld. 1998, 107, 5-14.

24. Batianoff, G.N.; Naylor, G.C.; Old, J.A.; Neldner, V.J. Climate and vegetation changes at coringa-herald national nature reserve, coral Sea islands, Australia. Pac. Sci. 2010, 64, 73-92. [CrossRef]

25. New South Wales Scientific Committee. Agnes BanksWoodland in the Sydney Basin Bioregion-Endangered ecological community Listing. New South Wales: National Parks and Wildlife Service. 2000. Available online: https:/ / www.environment.nsw.gov. au/determinations / AgnesBanksWoodlandSydneyEndComListing.htm (accessed on 14 February 2021).

26. Davila, Y.C.; Wardle, G.M. Bee boys and fly girls: Do pollinators prefer male or female umbels in protandrous parsnip, Trachymene incisa (Apiaceae)? Austral Ecol. 2007, 32, 798-807. [CrossRef]

27. Davila, Y.C.; Wardle, G.M. Variation in native pollinators in the absence of honeybees: Implications for reproductive success of an Australian generalist-pollinated herb Trachymene incisa (Apiaceae). Bot. J. Linn. Soc. 2008, 156, 479-490. [CrossRef]

28. Peter, K.V. Handbook of Herbs and Spices Vol. 2; Woodhead Publishing: Abington, UK, 2004.

29. Chizzola, R. Essential Oil Composition of Wild Growing Apiaceae from Europe and the Mediterranean. Nat. Prod. Commun. 2010, 5, 1477-1492. [CrossRef] [PubMed]

30. Habtemariam, S. Chapter 6-Introduction to plant secondary metabolites-From biosynthesis to chemistry and antidiabetic action. In Medicinal Foods as Potential Therapies for Type-2 Diabetes and Associated Diseases; Habtemariam, S., Ed.; Academic Press: Cambridge, MA, USA, 2019; pp. 109-132.

31. Hampel, D.; Mosandl, A.; Wüst, M. Biosynthesis of mono- and sesquiterpenes in carrot roots and leaves (Daucus carota L.): Metabolic cross talk of cytosolic mevalonate and plastidial methylerythritol phosphate pathways. Phytochemistry 2005, 66, 305-311. [CrossRef]

32. Palá-Paúl, J.; Brophy, J.J.; Goldsack, R.J.; Copeland, L.M.; Pérez-Alonso, M.J.; Velasco-Negueruela, A. Essential oil composition of the seasonal heterophyllous leaves of Eryngium vesiculosum from Australia. Aust. J. Bot. 2003, 51, 497-501. [CrossRef]

33. Palá-Paúl, J.; Pérez-Alonso, M.J.; Velasco-Negueruela, A.; Varadé, J.; Villa, A.M.; Sanz, J.; Brophy, J.J. Essential oil composition of the different parts of Eryngium bourgatii Gouan from Spain. J. Chromatogr. A 2005, 1074, 235-239. [CrossRef] [PubMed]

34. Palá-Paúl, J.; Pérez-Alonso, M.J.; Velasco-Negueruela, A.; Varadé, J.; Villa, A.M.; Sanz, J.; Brophy, J.J. Analysis of the essential oil composition of the different parts of Eryngium glaciale Boiss. from Spain. J. Chromatogr. A 2005, 1094, 179-182. [CrossRef] [PubMed]

35. Ballhorn, D.J.; Godschalx, A.L.; Smart, S.M.; Kautz, S.; Schadler, M. Chemical defense lowers plant competitiveness. Oecologia 2014, 176, 811-824. [CrossRef]

36. Fernandez, C.; Monnier, Y.; Santonja, M.; Gallet, C.; Weston, L.A.; Prévosto, B.; Saunier, A.; Baldy, V.; Bousquet-Mélou, A. The impact of competition and allelopathy on the trade-off between plant defense and growth in two contrasting tree species. Front. Plant Sci. 2016, 7, 594. [CrossRef]

37. Mirmostafaee, S.; Azizi, M.; Fujii, Y. Study of allelopathic interaction of essential oils from medicinal and aromatic plants on seed germination and seedling growth of lettuce. Agronomy 2020, 10, 163. [CrossRef]

38. Burns, J.H.; Strauss, S.Y. Effects of competition on phylogenetic signal and phenotypic plasticity in plant functional traits. Ecol. 2012, 93, 126-127. [CrossRef]

39. Cabal, C.; Martínez-García, R.; de Castro Aguilar, A.; Valladares, F.; Pacala, S.W. The exploitative segregation of plant roots. Science 2020, 4, 1197-1199. [CrossRef] [PubMed]

40. Brophy, J.J.; House, A.P.N.; Boland, D.J. Eucalyptus Leaf Oils-Use, Chemistry, Distillation and Marketing; Inkata Press: Melbourne, Auatralia; Sydney, Auatralia, 1991.

41. Stenhagen, E.; Abrahamsson, S.; McLafferty, F.W. Registry of Mass Spectral Data; Wiley: New York, NY, USA, 1974.

42. Heller, S.R.; Milne, G.W.A. EPA/NIH Mass Spectral Data Base; US Government Printing Office: Washington, DC, USA, 1978.

43. Swigar, A.A.; Silverstein, R.M. Monoterpenes; Aldrich: Milwaukee, WI, USA, 1981.

44. Adams, R.P. Identification of Essential oils Components by Gas Chromatography/Mass Spectroscopy; Allured Publishing Corporation: Carol Stream, IL, USA, 1995.

45. Joulain, D.; König, W.A. The Atlas of Spectral Data of Sesquiterpene Hydrocarbons; E. B.-Verlag: Hamburg, Germany, 1998.

46. Adams, R.P. Identification of Essential Oils Components by Gas Chromatography/Quadrupole Mass Spectroscopy; Allured Publishing Corporation: Carol Stream, IL, USA, 2001.

47. Adams, R.P. Identification of Essential Oil Components by Gas Chromatography_Mass Spectrometry, 4th ed.; Allured Publishing Corporation: Carol Stream, IL, USA, 2007.

48. Babushok, V.I.; Linstrom, P.J.; Zenkevich, I.G. Retention Indices for Frequently Reported Compounds of Plant Essential Oils. J. Phys. Chem. Ref. Data 2011, 40, 043101-043147. [CrossRef] 